\title{
FACTORS INFLUENCING THE HIGH SCHOOL GRADUATES' DECISION TO STUDY ABROAD: TOWARD A THEORETICAL MODEL
}

\author{
Boris Marjanović ${ }^{*}$ \\ Danijela Križman Pavlovic ${ }^{* *}$
}

Received: 9. 4. 2018

Review

Accepted: 18. 6. 2018

UDC 366.1-044.3>37(1-87)

DOI https://doi.org/10.30924/mjcmi/2018.23.1.221

\begin{abstract}
Institutions of higher education address the challenges of globalization by increasing their internationalization. This paper addresses the issue of consumers' decision-making in higher education, based on a literature review. The aim of this paper is to formulate a theoretical model, identifying and systematizing factors, influencing the high school graduates' decision to study abroad. The proposed model
\end{abstract}

\section{INTRODUCTION}

Globalization is driving the increasing internationalization of higher education. This manifests itself in open access that universities now have to the environment, i.e. enhancing educational programs with international focus, stronger presence on the international higher education market, and focus on research and development partnerships with international and global organizations (Maringe and Gibbs, 2009: 85). Therefore, globalization stimulates internationalization of universities (Maringe and Gibbs, 2009: 85 ) and provides an external impetus for consists of 114 factors, divided into six groups. The model allows the assessment of each factor and its influence on the student's decision, as well as the assessment of the factors' interactions. The model can be used by the stakeholders of the higher education system, as to define the policies and strategies of individual institutions.

Keywords: higher education, consumer's decision-making process, influencing factors, studying abroad, globalization.

accelerated institutional internationalization. Likewise, the process of internationalization of universities reinforces accelerated globalization (Maringe and Foskett, 2010: 17). Altbach and Knight (2007: 290) point out that globalization is an economic, political and societal power that pushes higher education of the 21 st century in the direction of greater international involvement.

Most of the leading higher education institutions (HEIs) tend to become global institutions involved in world-class research, focusing on social and scientific issues of global relevance, attracting first class students

\footnotetext{
*Boris Marjanović, PhD, Lecturer, Polytechnic Pula - College of applied sciences, Riva 6, 52100 Pula, Croatia, e-mail: bmarjanovic@politehnika-pula.hr

** Danijela Križman Pavlović, PhD, Professor, Juraj Dobrila University of Pula, Faculty of Economics and Tourism, Zagrebačka 30, 52100 Pula, Croatia, e-mail: dkrizman@unipu.hr
} 
and teaching staff from different parts of the world (Maringe and Foskett, 2010: 6). The marketing focus of HEIs has become more international due to the growing interest in recruiting students from abroad and the desire to increase global competitiveness (Maringe and Gibbs, 2009: 82). Motivation for internationalization includes commercial advantages, knowledge and language acquisition, curriculum improvement with international content, etc. Specific initiatives such as regional campuses, cross-border cooperation arrangements, programs for international students, establishment of courses in English, etc., represent the foundation of internationalization of higher education (Altbach and Knight, 2007: 290).

Maringe and Gibbs (2009: xii) point out several key arguments related to the application of marketing in higher education. Firstly, education is a key element of the development of society. Secondly, education should not be commercialized or reduced to a mere product whose sole purpose is to sell and generate profit. Education is a value that is transmitted in the process of interaction between a student, educational materials, teachers and all other resources involved in the education process. Thirdly, marketing as a concept goes beyond advertising and promotion, since it involves exchange and delivery of value between education providers and students. Ultimately, higher education marketing can be best understood as a model of collaborative relationship, which sees education as a humanistic process of chang, rather than a market transaction. From this standpoint, marketing attempts to build a relationship between the institution and the student, which increases the reputation of the education system and brings value to the institution (Gibbs, 2002: 333). Marketing should, therefore, be seen as a process of building a trust-based relationship with the aim of educating the (potential) student, and since marketing is a form of exchange and delivery of value, education needs to embrace the marketing philosophy (Maringe and Gibbs, 2009: xii).

Considering the noted tendency of internationalization of higher education, the research question is as follows: what factors influence the buying decision on a globalized higher education market? Literature review revealed that there is a lack of scientific papers that systematically and comprehensively explore the factors influencing the decision of high school graduates to study abroad. Therefore, the aim of this study is to formulate a theoretical model that will be used to identify and systematize these factors.

The paper is divided into two main parts. In the first part, the authors analyze current research on consumer behavior in general and on consumer behavior in the field of higher education. In the second part, the formulated consumer's decision-making process model on a globalized higher education market is explained.

\section{LITERATURE REVIEW}

\subsection{Consumer's decision-making process and influencing factors}

Modern marketing approach aims at satisfying consumer needs, and organizations have recognized that it is the only way to conduct a profitable business. The knowledge of factors influencing consumer behavior gives marketers the opportunity to direct marketing strategies to effectively meet consumer needs (Assael, 1998:3). In other words, marketing strategies must be based on factors that affect consumer behavior.

Consumer behavior can be defined as a series of psychological and physical activities that individuals or households undertake 
in the selection, purchase and consumption of products and/or services (Kesić and Piri Rajh, 2004:109). The outcome of consumer behavior is the making of a buying decision. The decision-making process is manifold and complex. It covers decisions from those ordinary to those highly structured (Kardes et al., 2011:181). Marketing experts have developed a model for the buying decisionmaking process (Figure 1). Consumers in the purchasing process go through five stages: need recognition, information search, evaluation of alternatives, purchase and post-purchase evaluation (Kotler and Keller, 2006:191). This five stage decision-making process model is applied when buying decisions are more complex. In complex decision-making, consumers value brands in a comprehensive and detailed way. More information is sought and more brands are evaluated than in any other decision situation (Assael, 1998:75).

There are various factors influencing the consumer's decision making process.
Considering the works of various authors (Kotler and Keller, 2006; Kerin et al., 2014; Grewal and Levy, 2013; Lancaster and Massingham, 2011; Hayden, 2009; Hawkins and Mothersbaugh, 2009; Dibb et al., 2012; Hoyer and MacInnis, 2008; Kotler, 2001) it is possible to notice that there is little consensus about the categorization of specific infl encing factors. Therefore, for the purpose of creating a theoretical model of the decisionmaking process, the following factors are systematized, described, and classified into defined groups as follows: 1) "Marketing mix", 2) "Macro environment factors", 3) "Situational factors", 4) "Psychological factors", 5) "Personal factors", 6) "Social factors", 7) "Cultural factors".

Table 1 displays systematized factors influencing the buying decision within the group called "Marketing Mix". This group includes four influencing factors, and it is evident that many authors have accepted the marketing mix instruments as factors infl encing the buying decision.

Figure 1: Five stage model of consumer's decision-making process (Kotler and Keller, 2006:191)

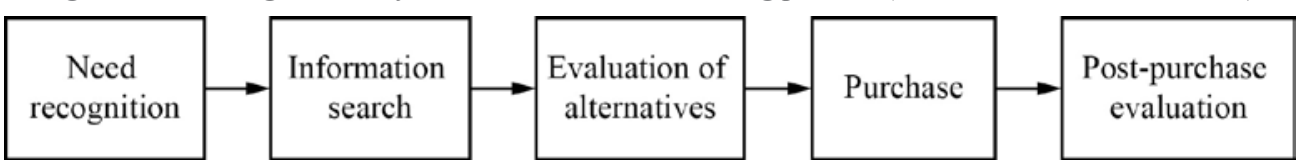

Table 1: Systematized factors in the "Marketing Mix" group

\begin{tabular}{|l|l|l|}
\hline $\begin{array}{l}\text { Influencing } \\
\text { factor group }\end{array}$ & $\begin{array}{l}\text { Influencing } \\
\text { factor }\end{array}$ & Authors \\
\hline Marketing mix & Product & $\begin{array}{l}\text { (Kotler and Keller, 2006), } \\
\text { (Kerin, Hartley and Rudelius, } \\
\text { 2014), (Grewal and Levy, 2013), } \\
\text { (Lancaster and Massingham, 2011), } \\
\text { (Hayden, 2009), (Hawkins and } \\
\text { Mothersbaugh, 2009) }\end{array}$ \\
\hline Price & Pistribution & \\
\hline
\end{tabular}

Source: Authors 
Journal of Contemporary Management Issues

Table 2: Systematized factors in the "Macro environment factors" group

\begin{tabular}{|l|l|l|}
\hline Influencing factor grou & Influencing facto & Authors \\
\hline \multirow{3}{*}{$\begin{array}{l}\text { Macro environment } \\
\text { factors }\end{array}$} & Economic & (Kotler and Keller, 2006) \\
\cline { 2 - 3 } & Technological & (Kotler and Keller, 2006) \\
\cline { 2 - 3 } & Political & (Kotler and Keller, 2006) \\
\cline { 2 - 3 } & Cultural & (Kotler and Keller, 2006) \\
\hline
\end{tabular}

Source: Authors

Table 3: Systematized factors in the "Situational factors" group

\begin{tabular}{|l|l|l|}
\hline $\begin{array}{l}\text { Influencing } \\
\text { factor group }\end{array}$ & Influencing facto & Authors \\
\hline $\begin{array}{l}\text { Situational } \\
\text { factors }\end{array}$ & Situational in general & (Dibb, et al., 2012), (Lancaster and Massingham, 2011) \\
\cline { 2 - 3 } & Purchase task & (Kerin et al., 2014), (Grewal and Levy, 2013) \\
\cline { 2 - 3 } & Social surroundings & (Kerin et al., 2014), (Grewal and Levy, 2013) \\
\cline { 2 - 3 } & Physical surroundings & (Kerin et al., 2014), (Grewal and Levy, 2013) \\
\cline { 2 - 3 } & Temporal effects & (Kerin et al., 2014), (Grewal and Levy, 2013) \\
\cline { 2 - 3 } & Antecedent states & (Kerin et al., 2014), (Grewal and Levy, 2013) \\
\hline
\end{tabular}

Source: Authors

Table 4: Systematized factors in the "Psychological factors" group

\begin{tabular}{|c|c|c|}
\hline $\begin{array}{l}\text { Influencing } \\
\text { factor group }\end{array}$ & $\begin{array}{l}\text { Influencing } \\
\text { factor }\end{array}$ & Authors \\
\hline \multirow[t]{8}{*}{$\begin{array}{l}\text { Psychological } \\
\text { factors }\end{array}$} & Motivation & $\begin{array}{l}\text { (Kotler and Keller, 2006), (Kerin, Hartley and Rudelius, 2014), } \\
\text { (Dibb et al., 2012), (Grewal and Levy, 2013), (Lancaster } \\
\text { and Massingham, 2011), (Hayden, 2009), (Hawkins and } \\
\text { Mothersbaugh, 2009), (Hoyer and MacInnis, 2008) }\end{array}$ \\
\hline & Perception & $\begin{array}{l}\text { (Kotler and Keller, 2006), (Kerin et al., 2014), (Dibb et al., } \\
\text { 2012), (Grewal and Levy, 2013), (Lancaster and Massingham, } \\
\text { 2011), (Hayden, 2009), (Hawkins and Mothersbaugh, 2009), } \\
\text { (Hoyer and MacInnis, 2008) }\end{array}$ \\
\hline & Learning & $\begin{array}{l}\text { (Kotler and Keller, 2006), (Kerin et al., 2014), (Dibb et al., } \\
\text { 2012), (Grewal and Levy, 2013), (Hayden, 2009), (Hawkins } \\
\text { and Mothersbaugh, 2009), (Hoyer and MacInnis, 2008) }\end{array}$ \\
\hline & Memory & $\begin{array}{l}\text { (Kotler and Keller, 2006), (Hawkins and Mothersbaugh, 2009), } \\
\text { (Hoyer and MacInnis, 2008) }\end{array}$ \\
\hline & Values & (Kerin et al., 2014), (Hoyer and MacInnis, 2008) \\
\hline & Beliefs & (Kotler, 2001), (Kerin et al., 2014) \\
\hline & Attitudes & $\begin{array}{l}\text { (Kotler, 2001), (Kerin et al., 2014), (Dibb et al., 2012), (Grewal } \\
\text { and Levy, 2013), (Lancaster and Massingham, 2011), (Hayden, } \\
\text { 2009), (Hawkins and Mothersbaugh, 2009) }\end{array}$ \\
\hline & Emotions & (Hawkins and Mothersbaugh, 2009) \\
\hline
\end{tabular}


Table 5: Systematized factors in the "Personal factors" group

\begin{tabular}{|l|l|l|}
\hline $\begin{array}{l}\text { Influencing } \\
\text { factor group }\end{array}$ & Influencing facto & Authors \\
\hline $\begin{array}{l}\text { Personal } \\
\text { factors }\end{array}$ & Demographics & $\begin{array}{l}\text { (Dibb et al., 2012), (Lancaster and Massingham, 2011), } \\
\text { (Hawkins and Mothersbaugh, 2009), (Hoyer and } \\
\text { MacInnis, 2008) }\end{array}$ \\
\cline { 2 - 3 } & Age and life-cycle stage & (Kotler, 2001), (Hoyer and MacInnis, 2008) \\
\cline { 2 - 3 } & Involvement & (Dibb et al., 2012) \\
\cline { 2 - 3 } & Economic situation & (Kotler, 2001), (Lancaster and Massingham, 2011) \\
\cline { 2 - 3 } & Ethnicity & (Hayden, 2009), (Hoyer and MacInnis, 2008) \\
\cline { 2 - 3 } & Lifestyle & $\begin{array}{l}\text { (Kotler, 2001), (Kerin et al., 2014), (Grewal and Levy, } \\
\text { 2013), (Lancaster and Massingham, 2011), (Hawkins } \\
\text { and Mothersbaugh, 2009), (Hoyer and MacInnis, 2008) }\end{array}$ \\
\cline { 2 - 3 } & Personality & $\begin{array}{l}\text { (Kotler, 2001), (Kerin, Hartley and Rudelius, 2014), } \\
\text { (Dibb, et al., 2012), (Lancaster and Massingham, 2011), } \\
\text { (Hawkins and Mothersbaugh, 2009), (Hawkins and } \\
\text { Mothersbaugh, 2009), (Hoyer and MacInnis, 2008) }\end{array}$ \\
\cline { 2 - 4 } & $\begin{array}{l}\text { (Kotler, 2001), (Hawkins and Mothersbaugh, 2009) } \\
\text { (Kotler, 2001) }\end{array}$ \\
\cline { 2 - 3 } & Self-Concept & Source: Authors \\
\cline { 2 - 3 } & Occupation &
\end{tabular}

Table 2 shows systematized factors influencing the buying decision in the group "Macroeconomic factors". This group encompasses four influential factors, and they have been identified in a single pape .

Table 3 displays a group of influential factors called "Situational factors". It consists of six factors. The research reveals that different authors adopt various positions regarding the issue of defining factors of infl ence in this group. Two sources only generalize situational factors, while the remaining two sources elaborate and detail factors of influence in this categor .

The following table (Table 4) displays a group of influential factors called "Psychological factors". The group consists of eight influential factors. As several authors mention systematized factors in their papers, it can be concluded that they tend to be generally accepted.

Table 5 shows outlined factors of buying decisions within the group titled "Personal factors". The group consists of nine factors of influence. It is evident that the authors partly agree regarding what influential factors should be included in this group of factors.

Next group of influential factors affecting the buying decision is titled "Social factors" (Table 6). This group consists of three influential factors. It can be concluded that there appears to be a consensus regarding the systematization of factors of influence in this group of factors. 
Journal of Contemporary Management Issues

Table 6: Systematized factors in the "Social factors" group

\begin{tabular}{|l|l|l|}
\hline $\begin{array}{l}\text { Influencing } \\
\text { factor group }\end{array}$ & Influencing facto & Authors \\
\hline Social factors & Reference groups & $\begin{array}{l}\text { (Kotler, 2001), (Kerin et al., 2014), (Dibb et al., 2012), } \\
\text { (Grewal and Levy, 2013), (Lancaster and Massingham, } \\
\text { 2011), (Hayden, 2009), (Hawkins and Mothersbaugh, } \\
\text { 2009), (Hoyer and MacInnis, 2008) }\end{array}$ \\
\cline { 2 - 3 } & & $\begin{array}{l}\text { (Kotler, 2001), (Kerin et al., 2014), (Dibb et al., 2012), } \\
\text { (Grewal and Levy, 2013), (Lancaster and Massingham, } \\
\text { Family }\end{array}$ \\
\cline { 2 - 3 } & $\begin{array}{l}\text { 2011), (Hawkins and Mothersbaugh, 2009), (Hoyer and } \\
\text { MacInnis, 2008) }\end{array}$ \\
\cline { 2 - 3 } & Social role and status & (Kotler, 2001), (Dibb et al., 2012) \\
\hline
\end{tabular}

Table 7: Systematized factors in the "Cultural factors" group

\begin{tabular}{|l|l|l|}
\hline $\begin{array}{l}\text { Influencing factor } \\
\text { group }\end{array}$ & $\begin{array}{l}\text { Influencing } \\
\text { factor }\end{array}$ & Authors \\
\hline Cultural factors & Culture & $\begin{array}{l}\text { (Kotler, 2001), (Kerin et al., 2014), (Dibb et al., 2012), } \\
\text { (Grewal and Levy, 2013), (Lancaster and Massingham, } \\
\text { 2011), (Hawkins and Mothersbaugh, 2009) }\end{array}$ \\
\cline { 2 - 3 } & Subculture & $\begin{array}{l}\text { (Kotler, 2001), (Kerin et al., 2014), (Dibb et al., 2012), } \\
\text { (Hawkins and Mothersbaugh, 2009) }\end{array}$ \\
\cline { 2 - 3 } & Religion & (Hayden, 2009), (Hoyer and MacInnis, 2008) \\
\cline { 2 - 3 } & Social class & $\begin{array}{l}\text { (Kotler, 2001), (Kerin et al., 2014), (Dibb et al., 2012), } \\
\text { (Lancaster and Massingham, 2011), (Hayden, 2009), } \\
\text { (Hawkins and Mothersbaugh, 2009), (Hoyer and MacInnis, } \\
\text { 2008) }\end{array}$ \\
\hline
\end{tabular}

Source: Authors

Table 7 shows systematized factors of influence from the group "Cultural factors". This group consists of four influential factors. It can be concluded that there is a consensus among researchers regarding the influential factors that belong to this group.

The analysis of previous research has identified 38 factors influencing the buying decision-making process, which are systematized into 7 groups. Below is an overview of current research related to the specifics of the buying decision-making process in the higher education market.

\subsection{Consumer's decision-making process on the higher education market}

A review of relevant literature reveals an absence of student's decision-making theoretical models of studying abroad. Therefore, written sources related to student's decision-making to study at home can serve as a guideline, because there are many similarities between the decision to study at home and that of studying abroad. A major similarity common to both of these decisions are financial outlays. Both decisions require 
considerable financial resources needed for an extended period of time. Second common aspect is location or place of study, which usually implies moving to a destination which is at considerable distance from the place of potential student's residence. Third issue involving both decisions includes taking into account the criteria such as academic quality and reputation or prestige of a HEI. Finally, the decision to study in both cases includes a number of complex influencin factors that need to be considered before making such an important decision (Anderson, 2007: 21-22).

Despite model variations, the basic decision-making model consists of five phases: problem recognition, information need, evaluation of alternatives, buying decision, and final evaluation of the buying decision (Kotler, 2003). In the context of higher education, the process generally consists of the following phases: 1) the pre-search phase, where the potential student passively reflects on the decision about their future education, 2) the phase of active search, in which the student creates a list of potential choices (institutions), 3) the application phase, during which the student submits the application to the selected institution, when student applies for admission to the selected institution, and makes decision on whether to accept or decline the offer, and 4) the post acceptance phase, in which the student reflects on whether the decision was right or wrong (Maringe and Carter, 2007: 460-461).

In the existing literature, several models of a HEI selection were developed: 1) econometric, sociological and combined models, 2) three-phase model of a higher education institution choice, 3) "push-pull" model, 4) international student decision-making process, 5) theory of planned behavior.

Econometric, sociological and combined models. Hossler et al., (1989: 234240) categorize the existing models of HEI choice as: econometric, sociological and combined. The econometric models attempt to predict the selection process on the basis of defining the intensity of certain factors, influencing the student's decision. Sociological models seek to identify the interdependencies of factors that influence the aspiration to pursue higher education. Combined models focus on the process and stages of HEI choice, rather than on the factors influencing this process. This model was suggested because sociological and econometric models did not provide an adequate interpretation of HEI choice from the aspect of the whole process.

Three-phase model of HEI choice. In this category, there are two approaches in defining the model of HEI choice. The first approach is the three-phase model, proposed by Hossler and Gallagher (1987), based on the previous research by Litten (1982) and Jackson (1982). This model describes the process in which students proceed from the initial stage of awareness about available higher educational options. Furthermore, the model describes the interdependence and mutual influence of personal and organizational factors on the formulation and definition of the student's final decision. The phases of this model are the following: predisposition phase, research phase and the choice phase (Hossler and Gallagher, 1987: 208-209).

"Push-Pull" model. Mazarol and Soutar (2002: 82) proposed a "Push-Pull" model of factors that influence the decision of students to study abroad. It suggests that the decision process of studying abroad consists of at least three stages: decision to study abroad, selection of the country of study and finally the selection of the institution of study. In the first stage, the students are influenced by the "push" factors, generated within their own country. Economic and social forces serve 
as "push" factors that influence students to leave their country, e.g. unfavorable political or social circumstances, a high level of unemployment, economic conditions, etc. The next stage is the selection of the country of study, and at this stage "pull" factors, making a country of choice relatively attractive, play a key role. Those could include the cost of living, the political and social security of a particular country, the low, or inexisting discrimination, the low crime rate, etc. In the third and final phase, students choose a specific HEI. At this stage, there are specific "pull" factors that make a particular institution more attractive than another. For example, this may include reputation or prestige of an institution, expertise of teaching staff, use of information technologies, marketing efforts, etc.

\section{International student decision-making} process. Cubillo et al. (2006) propose a theoretical model that integrates different groups of factors influencing the decision-making process of international students. This model assumes buying intention as a dependent and non-observable variable and four factors that consist of 19 independent variables identifie from existing studies. The identified factors are: personal reasons, country image and city image, reputation of the institution and program evaluation (Cubillo et al., 2006: 109). Personal reasons are, among other, personal advancement, future business opportunities and earnings, better professional status, while counselling involves the recommendations of family, friends, teachers and so on. The image of a country includes social reputation, academic reputation, the degree of country's development, cost of living etc. The factor of city image includes variables such as city size, living expenses, safety, social facilities etc. Image of an institution includes the following: prestige, ranking, academic reputation, researchers' reputation, quality of education, teaching staff expertise, social life at the institution, campus and so on. Program evaluation includes: international recognition, program suitability, program specialization, program quality, total costs, etc.

Theory of planned behavior. Ajzen's theory of planned behavior (1991) deals with the determinants of conscious behavior and is largely studied in the context of social psychology. It is also used in the wider context of behavioral science to predict and understand human behavior. Furthermore, it has been used as a theoretical basis for identifying the factors which might influence students' intention to study abroad. Specific behavior of a person is defined by his behavioral intent to manifest this behavior. Behavioral intent is defined by three determinants related to a specific behavior. The first determinant is attitude towards behavior (A) and refers to the degree to which a person has a favorable or unfavorable evaluation of the behavior in question. The second determinant is a social factor termed subjective norm (SN) and refers to the perceived social pressure to behave or not to behave in a certain way. The third determinant is perceived behavior control (PBC) and is defined as the ease or difficulty of performing the behavior. It is assumed to reflect past experience as well as anticipated impediments and obstacles. The general rule says: the more favorable the attitude and subjective norm with respect to a behavior, the greater the perceived behavioral control, the intent of the individual to conduct certain behavior should be greater (Presley et al., 2010: 233). The theory of planned behavior is an extension of the theory of reasoned action emerged as a necessity because of the limitations of the original model in the interpretation of behavior over which people have incomplete rational control (Ajzen, 1991: 181).

The presented models reveal that there is no single generally accepted model that can 
be used to describe the complex issue of student's behavior in the decision-making process to study abroad. Each of the proposed models addresses issues from a certain point of view. Anderson (2007: 21) points out that there is a lack of theoretical models for student decision-making to study abroad while according to Cubillo et al. (2006: 111-112) more studies have been conducted on the process of choice of higher education, but have been limited in focus with respect to the process itself. Only a few studies have focused on explaining the decision-making process from an integrated point of view.

\section{CONSUMER DECISION- MAKING PROCESS IN HIGHER EDUCATION: TOWARD A THEORETICAL MODEL}

\subsection{Research problem}

Continuous study of consumer behavior in higher education is considered essential for two reasons: 1) rising demand for highly educated employees, 2) rising of enrollment in tertiary education. The social benefit of higher education is reflected in increased national income and productivity, increased workforce productivity, increased economic activity in the HEI community, reduced cost of taxpayer funded social support programs, lower crime rates, etc. Attending higher education is necessary for a nation's social progress, its economic prosperity, and global competitiveness. It is a step forward from industrial, towards information and technology-driven economy (Perna, 2006: 102-103).

The benefits that students gain from completing higher education include a higher standard of living and higher income than individuals who have not completed higher education. Euromonitor International
Students of Tomorrow (2018) report reveals that global enrollment rates in the tertiary sector have increased from $35 \%$ in 2011 to $41 \%$ in 2016 . Furthermore, the same report shows that student mobility has significantly increased in recent decades, largely as a result of globalization. The number of students, studying abroad in 2017, more than doubled, when compared to 2000, and more than tripled, when compared to 1990. Countries like US, UK, Australia, Russia, Germany, France, Canada, Japan, China and Italy in 2016 constituted the most appealing markets for foreign students.

The focus of this study is to identify the factors, influencing the decision of high school graduates to enroll in a foreign HEI. Consumer behavior encompasses a range of psychological or physical activities that occur during the selection, purchase, and consumption of products or services. It is, therefore, essential to recognize the impact of these stimuli, whether of internal nature (such as motivation, perception or attitude) or external influences (such as marketing incentives in terms of products, prices, or promotions), because the influence of these stimuli will define the final consumer's buying decision.

There are many psychological and physical factors, external and internal influences that affect the choice of a potential student in terms of a study location and of a specific higher education institution. Knowledge of consumer behavior, specificall how a potential student evaluates the educational service (Cubillo et al., 2006: 102) and makes the decision, can bring HEIs significant advantage over the competition.

\subsection{Methodology}

As to formulate the model, presented in this study, the following steps were conducted: 1) the previous theoretical models 
were analyzed (Figure 1); 2) studies, related to factors, influencing the consumer's decision-making process in higher education were consulted; 3) the identified factors were categorized. The following methodological determinants should be pointed out as relevant for the selection of factors, influencing the consumer decision-making in higher education:

- The analysis of previous research has shown that some factors influencin the decision-making process to study at home overlap with factors related to the decision to study abroad (Anderson, 2007: 21-22). In previous studies, the authors did not emphasize the exclusivity of the influence of particular factors on only one context of study - at home or abroad. Therefore all factors infl encing the decision-making to study at home, relevant to this research, have also been taken into account.

- Certain factors have been well-considered and taken into consideration, even though the authors did not find an adequate background in the literature, such as "higher education institutions visiting high school institutions abroad".

- Only those influential factors that previous studies revealed as relevant in the context of making a decision to study abroad were taken into account.

- The authors primarily took into account the factors related to full-time study, but due to the similarity with the analyzed issue, the results of several studies related to short cycle studies, such as the Erasmus exchange program or other shorter professional courses abroad, were also taken into consideration.

- Factors that were taken into consideration were related to studies conducted on a sample of high school graduates and also of students at all levels of study, such as undergraduate, graduate and postgraduate studies.

- Factors that were taken into consideration were analyzed in two different contexts, during the different phases of the decision-making process (according to the Kotler model involving five phases): on a sample of high school students (during the information search and evaluation of alternatives) and on a sample of students in HEIs (after buying and during the post-buying evaluation).

- Only the factors relevant to high school graduates were considered. For example, "recommendations of lecturers and professors at HEIs, for the purpose of continuing education on a postgraduate study program" were not considered as an influential factor. In this context, recommendations of high school teachers are relevant to high school graduates.

- Only factors confirmed by previous studies were considered. Generic factors or factors that are not clearly defined by the authors in the literature have not been considered because of categorization problems. Therefore, only those factors that the authors have been able to categorize according to their own capabilities, abilities and knowledge have been taken into account.

The obtained consumer behavior model, relevant for HEIs, consists of five stages of the buying decision process with the categorized factors that affect the process.

\subsection{Theoretical model development}

The model is presented by Figure 2. It consists of 114 influential factors, which have been identified and categorized in the following six groups: 1) Marketing mix, 2) Macro environment factors, 3) Psychological factors, 4) Personal factors, 5) Social factors, and 6) Cultural factors (Marjanović, 2017: 92-125). Unlike 
Figure 2: Theoretical consumer decision-making model in higher education (Marjanović, 2017: 89)

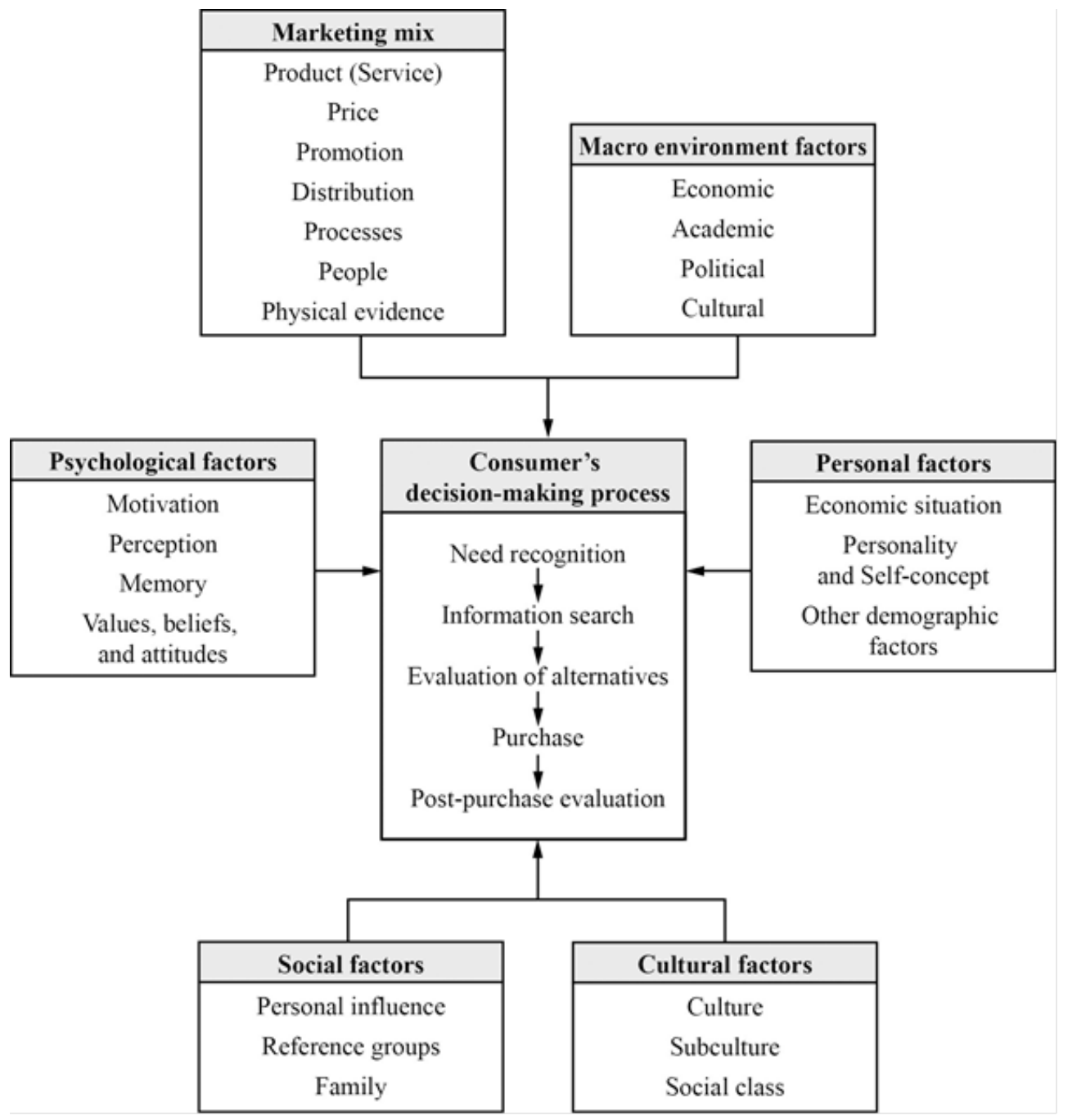

the generic buying decision-making model, the model, presented by Figure 2, excludes one group of factors that influence the HEI selection. Furthermore, the generic model excludes those factors, which were not supported by analyzed literature.

\section{Factors in the "Marketing mix" group} (1). Research has shown that service constitutes a key element for marketing HEIs. Potential students need to be provided with sufficient information about the offer of study programs and study outcomes, along with the information on the language of instruction and the language(s) spoken in the country of the selected HEI, since a low familiarity with foreign languages in the host country is an obstacle for international students (Phang, 2013: 32-33).

Cost can be a significant obstacle to studying abroad. Therefore, the cost of study 
should be taken into account as an important influential factor (Kasravi, 2009: 161), as well as additional possibilities of work during study and other living expenses (Binsardi and Ekwulugo, 2003: 324).

Cubillo et al. (2006: 109) state that the image of the country, in which a HEI is based, signific ntly influences the buying decision, but it is not the number one criteria weighted by the end users in choosing a foreign HEI. Students are inclined to choose institutions, located in urban settings, compared to those in rural areas (Hackney et al., 2012: 135).

In this process, students primarily rely on sources of information, provided by HEIs themselves. This includes brochures, leaflets, Web sites, open door events, etc. However, Web sites seem to be the most important and most used source of information for potential students (Simões and Soares, 2010: 376, 378). The importance of social networks as a promotional tool will grow in the future as they provide information about study programs and various events, and represent a rather widespread and popular media among potential students (Kusumawati, 2014: 130).

Processes, as instrument of service marketing, constitute an important factor in making decisions on selection of a foreign HEI (Binsardi and Ekwulugo 2003: 324). This particularly relates to the complexity of submitting applications, as well as processes for enrollment. Furthermore, acceptance of high school qualifications, as a condition for enrollment is one of the main factors in choosing a foreign HEI (Mazzarol and Soutar, 2002: 89).

Campus infrastructure, i.e. physical surroundings, such as accommodation and sports facilities, computer laboratories and study spaces, also represent an important factor (Cubillo et al., 2006: 108). Research conducted in Finland particularly emphasizes availability of accommodation (Hilden, 2011: 35). In addition to climate and lifestyle, perception of country attractiveness is significant, as well (Mazzarol and Soutar, 2002: 89) along with the international feel of the social environment (Hilden, 2011: 35). Mazzarol and Soutar (2002: 89) point out that a high amount of international students evokes positive perception among potential students about accepting foreigners in that environment.

This group includes the following factors:

- Subgroup "Product": 1) offer of the desired study program; 2) offer of a wide range of study programs; 3) applied technologies in the educational process; 4) offer of additional extracurricular courses/programs; 5) language of study.

- Subgroup "Price": 1) tuition fee; 2) other related living costs; 3 ) possibility of getting financial aid/scholarships

- Subgroup "Place": 1) the foreign country of study; 2) the foreign city of study; 3) distance of the HEI from the country/ place of residence; 4) urban/rural area of the study institution.

- Subgroup "Promotion": 1) visits to the HEI campus; 2) foreign HEI visits to high schools; 3) catalogs, leafle s, study guides, brochures and other printed materials; 4) newspapers, radio and television adds; 5) study institution Web site, 6) open days of the foreign HEI / university fairs, special events; 7) Facebook (HEI social network); 8) Instagram (HEI social network); 9) Twitter (HEI social network); 10) LinkedIn (HEI social network); 11) YouTube (HEI social network); 12) Google; 13) Flickr (HEI social network); 14) other social 
networks; 15) co-operation with other institutions.

- "Processes" subgroup: 1) the application process of foreign HEIs; 2) favorable enrollment conditions; 3) administrative support, respectful and prompt reaction of personnel at the foreign HEI.

- Subgroup “Staff”: personal contact with foreign institution representatives.

- Subgroup "Physical Environment": 1) availability of personal computers at the foreign HEI campus; 2) availability of a library at the campus; 3 ) availability of areas for self-study at campus; 4) availability of quiet places and relaxation facilities at campus; 5) availability of accommodation at campus; 6) availability of sports facilities at campus; 7) appearance / design of the campus; 8) physical climate at campus; 9) size of campus; 10) size of the city in which the HEI is located; 11) local infrastructure; 12) local social life; 13) social life in the foreign HEI; 14) size of the alumni association; 15) number of students per class / year; 16) multicultural environment and the number of international students.

Factors in the "Macro environment factors" group (2). Factors grouped into this category have been gathered within the country of origin of potential students (the so-called "push" factors) and factors generated from country where foreign institution of higher education is based (the so-called "pull" factors). The factors from the country of origin of potential students are significant because they "push" or motivate potential students to leave their country. Research has shown that some of the most significant factors include unfavorable economic, political and academic situation. Students from less developed countries tend to study abroad because the environment in their home country is unfavorable, particularly from the economic perspective (McMahon, 1992: 476). Accordingly, other related research shows that a certain population of international students chooses to study abroad, because they want to get away from poverty or political unrest present in their own coutries (Zeeshan et al., 2013: 839). Political instability of the home country is also a reason for leaving (Kent-Wilkinson et al., 2015: 1; Mpinganjira, 2009: 362). McCarthy et al. (2012: 449) claim that when it comes to undergraduate study curriculum the insufficiency of studying programmes at home country constitutes one of the most significant factors influencing the decision to choose a foreign HEI. This is confirmed by Mazzarol and Soutar (2002: 88), who argue that complexity of enrollment into domestic HEIs is relevant, as well.

Research has shown that favorable economic, political and social situations constitute some of the most significant factors at the country level. Cubillo et al. (2006: 108) and Chen and Zimitat (2006: 97) point out that the economic power of the country, in which a HEI is located, represents an infl ential "pull" factor. The strongest influence among "pull" factors from this category are related to political and social stability (Hilden, 2011: 35) and a low/inexisting discrimination (Mazzarol and Soutar, 2002: 89).

This group includes the following factors:

- Sub-group "Academic factors": 1) unavailability of the programme of study in home country; 2) lack of educational opportunities at HEIs in home country; 3) very demanding enrollment conditions in HEIs in home country; 4) inadequate teaching facilities / research capabilities in home country.

- Sub-group "Socio-cultural factors": a low discrimination rate in the foreign 
country of study.

- Subgroup "Economic factors": 1) level of economic development in the foreign country of study; 2) level of economic development in home country; 3) current unemployment rate in home country.

- Subgroup "Political-legal factors": 1) degree of political and social security in the country of study; 2) low rate of corruption and a high level of fairness and honesty in the country of study; 3 ) possibility of immigration to the country of study after graduation; 4) ease of obtaining a student visa; 5) low crime rate in the country of study; 6) political situation in home country.

Factors in the "Psychological factors" group (3). Motivation is considered as one of the most powerful pshychological factors as it "pushes" an individual to act. Studying abroad provides students with education, but also brings them new life experiences with particular emphasis on personal growth (Kent-Wilkinson et al., 2015: 1). Another survey points out to a series of factors of influence categorized under the title "experience-oriented results", including life and study abroad (Mpinganjira, 2009: 361). International students pointed out the importance of study abroad because to a large extent it allows them to acquire international experience, which helps them gain better understanding of global issues and points of views (Zeeshan et al., 2013: 841-842).

Studies have shown that surveyed individuals consider the following as benefits from studying abroad: potential to acquire independence, i.e. become self-sufficient (Kent-Wilkinson et al., 2015: 5), develop cquire new skills (Chen and Zimitat, 2006: 97) and competencies (Kent-Wilkinson et al., 2015: 5). Furthermore, it is pointed out that learning a foreign language represents a primary academic outcome, and this is a personal factor students single out as essential for studying abroad (Kasravi, 2009: 155). Employment opportunity is one of the key reasons for studying abroad as it adds value to the graduated student, either on the home labor market, or because student plans to migrate to the country of foreign HEI after graduation (McCarthy, Sen and Garrity, 2012: 449). It also enables the student to attain a higher social status (Mpinganjira, 2009: 360).

Perception is the psychological factor that proved to be significant when making a buying decision in higher education. Studies show that perceived reputation of institution of higher education has a direct impact on selection of institution of higher education and, alongside the rating and prestige of an institution, it represents one of the most significant factors of influence (Phang, 2013: 32). Perceived high educational standards and degree recognized globally represent the main reasons why students choose to continue their education in United Kingdom (Binsardi and Ekwulugo 2003: 324). Mazzarol and Soutar (2002: 89) confirm the value and prestige of the degree as being a significant factor of influence in this context. Quality of education also represents a significant "pull" factor of attractiveness of a country in which the foreign HEI is located (Zeeshan et al., 2013: 839). The quality of education is linked to the perception of expertise and the quality of the teaching staff. The above stated makes a HEI more attractive than others (Zeeshan et al., 2013: 841).

This group includes the following factors:

- Subgroup "Motivation": 1) obtaining new life experiences; 2) developing a global perspective or a "global worldview"; 3) desire for adventure, entertainment, traveling and pleasure; 4) new 
insights and understanding of other cultures; 5) gaining independence; 6) obtaining new knowledge and developing new skills, acquiring the ability of critical thinking, and developing cognitive abilities; 7) improving language skills; 8) achieving self-confidence, motivation and more self-initiative; 9) reaching a higher social status; 10) improvement of the quality of life in future; 11) meeting new people / friends (international contacts); 12) better employment opportunities; 13) perspective of getting a better job; 14) earning higher income; 15) achieving professional growth and perspective for better professional opportunities; 16) achievement of personal growth and development, better understanding of personal values and beliefs; 17) addressing a professional challenge; 18) addressing a personal challenge; 19) addressing a personal desire.

- Subgroup "Perception": 1) academic and social reputation of a foreign country; 2) reputation of the city/ micro-location; 3) academic and social reputation and prestige of the foreign HEI; 4) value, reputation and prestige of the foreign diploma in the domestic and foreign labor market; 5) perceived higher quality of education in a foreign country; 6) perceived higher quality of education and programs at the foreign educational institution; 7) perceived higher quality, reputation and expertise of teaching and research staff at the foreign HEI; 8) perceived higher personal and professional benefits, expectations, values and beliefs about the outcomes of studying abroad; 9) negative prospects for employment in home country in the near future.

- Subgroup "Memory": previous knowledge and awareness of the foreign country of study.
- Subgroup "Values": respect and understanding of other cultures.

- Subgroup "Attitude": 1) positive attitude towards education abroad; 2) positive attitude towards other cultures.

Factors in the "Personal factors" group (4). Personal factors influence buying decision at the individual level and, generally, include the personality and the fina cial means. Personality represents relatively permanent characteristics of an individual that influence the quality of interaction with other persons and situations. Students' inclination towards making a decision to study abroad can be linked to openness and attitude towards the unknown. Individuals, who tend to be more open are inclined to working in multicultural environment, as well as those, with a positive attitude toward the unknown, are expected to perceive a departure to another country as an exciting and positive experience, rather than as anstacle and burden (Bakalis and Joiner, 2004: 287).

Financial means are essential in making the decision to study abroad. Opportunities for local employment during the study for international students in the United Kingdom are significant (Binsardi and Ekwulugo 2003:324). Another research shows that parents' financial support is also important factor for making the decision to study abroad (Pope and Fermin, 2003: 21). Hence, family's financial situation is a very important factor in making the decision to study abroad.

This group includes the following factors: 1) openness; 2) dealing with unknown events; 3) possibilities of local employment during the study; 4) financial support from the family.

Factors in the "Social factors" group (5). Studies prove that social environment of potential students has a significant role in 
making a buying decision on the globalized market for higher education. The most important factor affecting the intention to study abroad (based on survey of Taiwanese survey participants) includes family and friends (Chen and Zimitat, 2006: 98). Furthermore, a survey carried out among Thai students shows that parents and siblings have a significant influence on making a decision to study abroad (Tarry, 2008: 125). Another study shows that advice of professors, friends and family might not be so significant for a decision to study abroad, which directs the HEI marketing activities to exclusively target the potential students, instead of their social surroundings (Hilden, 2011: 35). This indicates that various groups of surveyed populations do not evaluate the stated factors of infl ence in the same way.

According to a survey conducted by Phang (2013: 35), family and friends have a positive influence on the decision of international students to choose studying in Sweden, because international students believe that information they receive from the stated sources are reliable and true. Likewise, other students who already studied abroad, peers and other significant persons represent relevant source of information (Kasravi, 2009: 156).

A study conducted in Poland showed that potential foreign students most frequently use Internet as a source of information, i.e. particularly HEI Web sites, as well as different discussion forums (Sojkin et al., 2012: 571). Mazzarol and Soutar (2002: 85) stress that word-of-mouth recommendations by those who already studied abroad constitute an important source of information to potential international students, particularly when it comes to recommendation of the family members.

This group includes the following factors: 1) parents; 2) siblings; 3 ) other relatives
/ family in general; 4) friends / colleagues / fiancé(e); 5) friends / siblings / relatives who studied or study abroad; 6) friends / siblings / relatives who lived or live abroad; 7) religious influenc ; 8) alumni association of foreign higher education institution; 9) high school teachers; 10) school advisers/agents/ others; 11) opinion of students and other significant individuals; 12) information on online forums, social networks and other independent Web portals; 13) ranking of higher education institutions ; 14) word of mouth.

Factors in the "Cultural factors" group (6). Knowledge of foreign language and understanding of other cultures tend to be in direct correlation with a need to understand the world we live in (Kasravi, 2009: 12). Learning a foreign language and understanding other culture have a direct influence on individual's appreciation of a country's culture (Cubillo et al., 2006: 109).

Social, academic but also racial / ethnic climate (Dean et al., 2006: 19) appear to be significant factors in making a decision to study in a different country, which provides an additional advantage to HEIs, located in multi-cultural countries, or those, which are already hosting a large body of international students.

Culture and education acquired at home play an important role when international students make the decision on the country to study in. In conservative countries, families might tend to resist their children's wishes to study abroad (Fardan and Belrehif, 2012: 49) which points out that family upbringing and culture are significant influential factors.

This group includes the following factors: 1) linguistic and cultural differences; 2) ethnicity and race, 3 ) cultural influence in general. 


\section{DISCUSSION AND CONCLUSION}

The value of higher education can be understood in a narrower and wider context, given the two key interested parties: state administration bodies and higher education institutions at home and abroad. In the broader context, the value of higher education can be expressed in terms of "knowledge". In the knowledge-based economy, knowledge and intellectual capital are the most prominent drivers of growth and development, through innovation, new ideas and ways of action. Education institutions are the main source of experts for the labor market and are largely responsible for the learning outcomes, competences and expertise. The value of higher education in a narrow context can be viewed from the aspect of benefits to higher education institutions.

The area of interest for a HEI is the understanding of reasons why high school graduates continue their education and what factors influence their sudy-related decisions. The decision to continue education can be observed from the point of view of study at home country and study abroad. Globalization, as a phenomenon of the modern era, opens up national borders and, in the business context, creates a global market. For higher education, this is a chance but also a threat. On the one hand, higher education institutions are present on the international market, allowing them to attract more students, but on the other hand, opening of national borders exposes them to a highly competitive market Therefore, marketing in higher education is no longer an option, but a need.

The main focus of this study is on factors influencing the decision to study abroad. There is a number of psychological and physical factors influencing such decision of a high school graduate. For higher education institutions, knowledge of consumer behavior and factors influencing the decision of high school graduates, when choosing a foreign HEI, can bring significant advantage on the global market. Therefore, the purpose of this research is to gain a better insight into the behavior of consumers in the higher education market affected by globalization.

The theoretical implications of the research consist of the formulation of the theoretical consumer's decision-making model in higher education, which, along with the five-phase process, consists of 114 identified influential factors. They are systematized into the following six groups: "Marketing mix", "Macro environment factors", "Psychological factors", "Personal factors", "Social factors", and "Cultural factors".

Practical implications of this paper relate to the application of research results when defining policies and strategies, used by various stakeholders of higher education. It allows measurement of the intensity of the influence, exerted by each of the identified factors, as well as assessment of how significant is each of the factor groups. By understanding what influences the high school graduates' decision to study abroad, this study could assist HEIs in formulating their offers, designing promotional efforts, etc.

A limitation of this research is related to the applied methodology, used to systematize the identified influential factors. When performing the literature review, the researchers came across factors that were either not clearly defined or they could not be allocated to some of the pre-defined categories. This constitutes the potential for improving the proposed theoretical model, which should be, also, empirically tested in future research. 


\section{REFERENCES}

1. Ajzen, I. (1991). The theory of planned behavior.

Organizational

Behavior and Human Decision Processes, 50(2), 179-211.

2. Altbach, P. G., and Knight, J. (2007). The internationalization of higher education: Motivations and realities. Journal of Studies in International Education, 11(3-4), 290-305.

3. Anderson, B. D. (2007). Students in a global village: The nexus of choice, expectation, and experience in study abroad (Doctoral dissertation). Austin: University of Texas.

4. Assael, H. (1998). Consumer Behavior and Marketing Action. Cincinnati, Ohio: South-Western College Publishing.

5. Bakalis, S., \& Joiner, T. A. (2004). Participation in tertiary study abroad programs: The role of personality. International Journal of Educational Management, 18(5), 286-291.

6. Binsardi, A., \& Ekwulugo, F. (2003). International marketing of British education: research on the students' perception and the UK market penetration. Marketing Intelligence \& Planning, 21(5), 318-327.

7. Chen, C. H., \& Zimitat, C. (2006). Understanding Taiwanese students' decision-making factors regarding Australian international higher education. International Journal of Educational Management, 20(2), 91-100.

8. Cubillo, M. J., Sánchez, J., and Cerviño, J. (2006). International students' decision-making process. International Journal of Educational Management, 20(2), 101-115.

9. Dean, D. R., Hunt, E. L., and Smith, R. (2006). Committing to Keep Illinois
Students In-State: Understanding College Choice, Student Migration Patterns, and Retention Strategies. Center for the Study of Education Policy.

10. Dibb, S., Simkin, L., Pride, W. M., and Ferrell, O. (2012). Marketing Concepts and Strategies (6th edition). Boston: Cengage Learning.

11. Fardan, H. A., and Belrehif, F. (2012). Making Higher Education Choices in Dubai. Dubai: Dubai School of Government.

12. Gibbs, P. (2002). From the invisible hand to the invisible handshake: marketing higher education. Research in postcompulsory education, 7(3), 325-338.

13. Grewal, D., and Levy, M. (2013). Marketing (4th Edition). New York: McGraw-Hill Education.

14. Hackney, K., Boggs, D., and Borozan, A. (2012). An empirical study of student willingness to study abroad. Journal of Teaching in International Business, 23(2), 123-144.

15. Hawkins, D., and Mothersbaugh, D. (2009). Consumer behavior build-ing marketing strategy. New York: McGraw-Hill.

16. Hayden, N. (2009). Basics Marketing 01: Consumer Behaviour.

Lausanne: AVA Publishing.

17. Hildén, M. (2011). International Students' Decision-Making Process. (Bachelor thesis, Lappeenranta University of Technology).

18. Hossler, D., Braxton, J., and Coopersmith, G. (1989). Understanding student college choice. Higher educa-tion: Handbook of theory and research, 5, 231-288.

19. Hossler, D., and Gallagher, K. S. (1987). Studying Student College 
Choice: A Three-Phase Model and the Implications for Policymakers. College and University, 62(3), 207-221.

20. Hoyer, W. D., and MacInnis, D. J. (2008). Consumer Behavior.

Boston: Cengage Learning.

21. Jackson, G. (1982). Public efficienc and private choice in higher education. Educational Evaluation and Policy Analysis, 4 (2), 237-247.

22. Kardes, F. R., Cronley, M. L., \& Cline, T. W. (2011). Consumer Behavior, Mason, OH: South-Western, Cengage Learning.

23. Kasravi, J. (2009). Factors influencin the decision to study abroad for students of color: Moving beyond the barriers. (Doctoral dissertation, University of Minnesota).

24. Kent-Wilkinson, A., Leurer, M. D., Luimes, J., Ferguson, L., and Murray, L. (2015). Studying abroad: Exploring factors influencing nursing students' decisions to apply for clinical placements in international settings. Nurse Education Today, 35 (8), 941-947.

25. Kerin, R. A., Hartley, S. W., and Rudelius, W. (2014). Marketing (12 edition). New York: McGraw-Hill Education.

26. Kesić, T., Piri Rajh, S. (2004). 5. Ponašanje potrošača. In Previšić, J., and Ozretić Došen, Đ. (Eds.). (2004). Marketing (II. izmijenjeno i dopunjeno izdanje ed.). Zagreb: Adverta.

27. Kotler, P. (2001). Upravljanje marketingom: analiza, planiranje, primjena $\mathrm{i}$ kontrola. Zagreb: Mate.

28. Kotler, P., and Keller, K. L. (2006). Marketing management. New Jersey: Prentice Hall.

29. Kusumawati, A. (2014). Social Networking Sites for University Search and Selection. Journal of Education and Practice, 5(25), 130-142.

30. Lancaster, G., and Massingham, L. (2011). Essentials of Marketing Management. Abingdon: Routledge.

31. Maringe, F., and Carter, S. (2007). International students' motivations for studying in UK HE: Insights into the choice and decision making of African students. International Journal of Educational Management, 21(6), 459-475.

32. Maringe, F., and Gibbs, P. (2009). Marketing Higher Education - Theory and Practice. London: Open University Press.

33. Maringe, F., and Foskett, N. (2010). Globalization and Internationalization in Higher Education - Theoretical, Strategic and Management Perspectives. New York: Continuum Publishing Group.

34. Marjanović, B. (2017). Ponašanje potrošača u visokom obrazovanju - izbor obrazovne institucije na globaliziranom tržištu (Consumer behavior in higher education: Selection of a higher education institution on a global market. Doctoral dissertation). Osijek: Josip Juraj Strossmayer University of Osijek, Faculty of Economics.

35. Mazzarol, T. (1998). Critical success factors for international education marketing. International Journal of Educational Management, 12(4), 163-175.

36. Mazzarol, T., and Soutar, G. N. (2002). "Push-pull" factors influencin international student destination choice. International Journal of Educational Management, 16(2), 82-90.

37. McCarthy, E. E., Sen, A. K., and Garrity, B. F. (2012). Cross-Border Education: Factors Influencing Canadian Students' 
Choice of Institutions of Higher Education in the United States. Global Conference on Business and Finance Proceedings, 7(1), 446-457.

38. McMahon, M. E. (1992). Higher education in a world market. Higher education, 24(4), 465-482.

39. Mpinganjira, M. (2009). Comparative analysis of factors influencing the decision to study abroad. African Journal of Business Management, 3(8), 358-365.

40. Mudie, P., and Pirrie, A. (2006). Services Marketing Management. Oxford: Butterworth-Heinemann.

41. Litten, L.H. (1982). Different strokes in the applicant pool: Some refinements in a model of students choice. Journal of Higher Education, 4, 383-402.

42. Perna, L. W. (2006). Studying college access and choice: A proposed conceptual model. Higher Education, 99-157.

43. Phang, S. L. (2013). Factors influen ing international students' study destination decision abroad. (Master thesis, University of Gothenburg).

44. Pope, M. L., and Fermin, B. (2003). The perceptions of college students regarding the factors most influential in their decision to attend postsecondary education. College and University, 78(4), $19-25$.
45. Presley, A., Damron-Martinez, D., and Zhang, L. (2010). A study of business student choice to study abroad: A test of the theory of planned behavior. Journal of Teaching in International Business, 21(4), 227-247.

46. Shostack, L. G. (1982). How to design a service. European Journal of Marketing, 16(1), 49-63.

47. Simões, C., and Soares, A. M. (2010). Applying to higher education: information sources and choice factors. Studies in Higher Education, 35(4), 371-389.

48. Sojkin, B., Bartkowiak, P., and Skuza, A. (2012). Determinants of higher education choices and student satisfaction: The case of Poland. Higher Education, 63(5), 565-581.

49. Students of Tomorrow - Global Trends Driving Demand for Education (2018). Euromonitor International.

50. Tarry, E. F. (2008). Thai students and their reasons for choosing to study in United Kingdom universities (Doctoral dissertation, University of Bath).

51. Zeeshan, M., Sabbar, S. D., Bashir, S., \& Hussain, R. I. (2013). Foreign students' motivation for studying in Malaysia. International Journal of Asian Social Science, 3(3), 833-846. 


\section{ČIMBENICI UTJECAJA NA ODLUKU MATURANATA O STUDIJU U INOZEMSTVU: PREMA TEORIJSKOM MODELU}

\section{SAŽETAK}

Institucije visokog obrazovanja reagiraju na izazove globalizacije povećanjem razine svoje internacionalizacije. U ovom se radu, na temelju pregleda literature, raspravlja o problemu odlučivanja o potrošnji korisnika visokog obrazovanja. Cilj rada je formulirati teorijski model, koji identificira i sistematizira čimbenike utjecaja na odluku maturanata o studiju $u$ inozemstvu. Predloženi se model sastoji od 114 faktora, podijeljenih u šest skupina. Model omogućava mjerenje intenziteta utjecaja svakog od čimbenika na odluku o potrošnji, kao $i$ procjenu značaja svih skupina čimbenika. Model mogu ga koristiti svi dionici sustava visokog obrazovanja za utvrđivanje politika i strategija pojedinih institucija. 